\title{
Fitz-Hugh-Curtis syndrome: a case of perihepatitis in 'mosaic' pattern
}

\author{
Verena Pires (10, ${ }^{1}$ Mariana Sucena, ${ }^{2}$ Susana Basso ${ }^{1}$
}

${ }^{1}$ Department of Radiology,

Centro Hospitalar e Universitário de Coimbra EPE, Coimbra, Portugal

${ }^{2}$ Department of Gynecology, Centro Hospitalar e Universitário de Coimbra EPE, Coimbra, Portugal

\section{Correspondence to}

Dr Verena Pires;

verena_pires@hotmail.com

Accepted 6 February 2022

\section{Check for updates}

(C) BMJ Publishing Group Limited 2022. No commercial re-use. See rights and permissions. Published by BMJ.

To cite: Pires V, Sucena M,
Basso S. BMJ Case Rep
2022;15:e248744.
doi:10.1136/bcr-2022-
248744

\section{DESCRIPTION}

A 24-year-old woman was presented to our emergency department with fever and right upper abdominal pain for 4 days, which worsened with deep breathing. Two weeks earlier, she was treated for possible cystitis with nitrofurantoin and she had treatment for bacterial vaginosis. There was no significant medical history or history of recent highrisk sexual intercourse.

Physical examination revealed pain on abdominal palpation in particular at the level of the right upper quadrant. There was no Murphy's sign. The patient was haemodynamically stable with a blood pressure of $132 / 84 \mathrm{~mm} \mathrm{Hg}$, respiration rate of 18 breaths per minute and a pulse of 74 beats per minute, and there were no signs of heart failure. Laboratory tests demonstrated an increased level of $\mathrm{C}$ reactive protein value, mild leucocytosis, negative serum pregnancy test and normal liver function. The ultrasound showed hepatomegaly with no gallbladder and appendiceal pathologies. Abdominal contrastenhanced CT scan (figure 1) showed hepatomegaly with an enhancement of the hepatic capsule of the right lobe. Additionally, there was periportal oedema with inhomogeneous mottled pattern due to heterogenous perfusion of the liver consistent, commonly referred to as a 'mosaic' enhancement pattern. This patient could be considered to have a Budd-Chiari syndrome (BCS) but no venous thrombosis was present. In conjunction with these findings, the patient was admitted for follow-up and treatment. MRI (figure 2) was performed to further elucidate the findings and showed free fluid in the pouch of Douglas, enlarged right ovary with a heterogeneous cystic compatible with tubo-ovarian abscess. During hospitalisation, a serological study yielded positive results for both serum Chlamydia trachomatis immunoglobulin IgA and IgG. A PCR study of a cervical mucus sample was positive as well. These history and imaging findings are suggestive of Fitz-Hugh-Curtis syndrome (FHCS). The patient was treated with intravenous antibiotics (doxycycline, ceftriaxone and metronidazole). After 8 days, she was discharged with a 14 days course of doxycycline and clindamicine and recovered well.

FHCS is a rare complication of pelvic inflammatory disease. This condition is characterised by perihepatitis defined as an inflammation of the liver capsule to result from the intraperitoneal spread of pelvic inflammatory disease. There is no single diagnosis goldstandard, so it may be misdiagnosed as many other disorders like acute cholecystitis, right pyelonephritis, pneumonia and even acute appendicitis. ${ }^{1-5}$

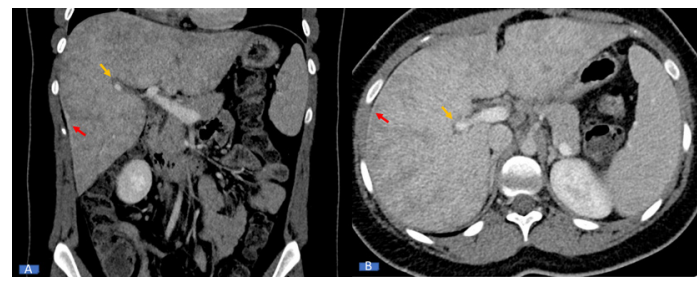

Figure 1 Coronal (A) and axial (B) CT during portal venous phase showed hepatomegaly with enhanced thickening of liver capsule associated with heterogenous enhancement and a 'mosaic' appearance (red arrow). Additionally, there was a periportal oedema present also referred to as the periportal halo sign (yellow arrow).

In the past, the diagnosis was made by visual or laparoscopic inspection, showing the perihepatic adhesions and the treatment was made by adhesiotomy. Now, with the development of imaging strategies, it can be diagnosed by non-invasive methods. ${ }^{1}$ The syndrome can be cured by oral administrations of appropriative antibiotics such as tetracycline, doxycycline or erythromycin. ${ }^{6}$ On the other hand, surgical treatment (laparoscopic adhesiolysis) can be preferred only for cases that were unresponsive to antibiotic therapy. ${ }^{1}$

Stasis of blood within hepatic sinusoids and the altered haemodynamics that occur with hepatic venous outflow obstruction manifest as a 'mosaic' enhancement of the hepatic parenchyma. Hepatic venous outflow obstruction can occur at the following different levels: the heart (in the setting of congestive heart failure such as tricuspid regurgitation, cardiomyopathy, constrictive pericarditis and core pulmonale), inferior vena cava (IVC), hepatic veins (BCS) and at the level of sinusoids and central veins (sinusoidal obstruction syndrome (SOS)). However, a mosaic pattern of enhancement is not entirely specific for hepatic venous outflow obstruction. Hepatic sinusoidal dilatation can also

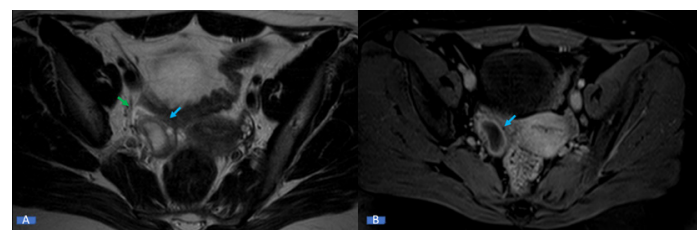

Figure 2 (A) Axial T2-weighted image showed adnexal heterogeneous cystic lesion. (B) Axial contrastenhanced T1-weighted image demonstrated thick wall enhancement compatible with tubo-ovarian abscess (blue arrow). Additionally, there was free fluid around the right ovary (green arrow). Left ovary was normal. 
be seen in the absence of hepatic venous outflow obstruction in some extrahepatic inflammatory and infectious conditions, such as pyelonephritis, cholecystitis, pneumonia, pancreatitis, intestinal bowel disease and others. ${ }^{78}$

In this patient, there was no hepatic venous outflow obstruction, thus the 'mosaic' pattern could be likely due to the progress and infiltration of the inflammatory process. The history of vaginal infection treated 2 weeks earlier associated with all of these imaging findings such as hepatic capsular enhancement, pain characteristics and inflammatory parameters lead us to correct diagnosis and no surgical interventions were needed.

\section{Patient's perspective}

In my case with the proper treatment, the symptoms were resolved immediately and no surgical interventions were needed. I'm very happy about the staff hospital and hope that my case helps other patients with the same problem as me.

\section{Learning points}

- Perihepatic and capsular inflammatory process can result in secondary local inflammation of the periportal regions causing a 'mosaic' pattern.

- This rare syndrome should be kept in mind in the differential diagnosis of acute abdominal pain in any reproductive aged woman to avoid unnecessary surgery, invasive treatments and thus to retain fertility.
Contributors VP wrote the manuscript. MS was the assisting physician in the mentioned case. MS and SB critically reviewed and gave the final suggestions. All authors contributed to finalising the manuscript as submitted.

Funding The authors have not declared a specific grant for this research from any funding agency in the public, commercial or not-for-profit sectors.

Competing interests None declared.

Patient consent for publication Consent obtained directly from patient(s).

Provenance and peer review Not commissioned; externally peer reviewed.

Case reports provide a valuable learning resource for the scientific community and can indicate areas of interest for future research. They should not be used in isolation to guide treatment choices or public health policy.

\section{ORCID iD}

Verena Pires http://orcid.org/0000-0002-3538-7757

\section{REFERENCES}

1 Çiftci $A B$, Ocak S, Taylan A. Fitz-hugh-curtis syndrome: a rare disease in the differential diagnosis of acute abdomen. GMJ 2020;62:206-8

2 de Boer JP, Verpalen IM, Gabriëls RY, et al. Fitz-Hugh-Curtis syndrome resulting in Nutmeg liver on computed tomography. Radio/ Case Rep 2019;14:930-3.

3 Wang P-Y, Zhang L, Wang X, et al. Fitz-Hugh-Curtis syndrome: clinical diagnostic value of dynamic enhanced MSCT. J Phys Ther Sci 2015;27:1641-4.

4 Sahli H, Taibi B, Boukhalit H, et al. Perihepatitis (Fitz-Hugh-Curtis syndrome): case report and review of literature. Int J Case Rep Imag 2021;12:1.

5 Pickhardt PJ, Fleishman MJ, Fisher AJ. Fitz-Hugh-Curtis syndrome: multidetector CT findings of transient hepatic attenuation difference and gallbladder wall thickening. AJR Am J Roentgenol 2003;180:1605-6.

6 Nishie A, Yoshimitsu K, Irie H, et al. Fitz-Hugh-Curtis syndrome. radiologic manifestation. J Comput Assist Tomogr 2003:27:786-91.

7 Brancatelli G, Furlan A, Calandra A, et al. Hepatic sinusoidal dilatation. Abdom Radiol 2018;43:2011-22

8 Furlan A, Minervini MI, Borhani AA, et al. Hepatic sinusoidal dilatation: a review of causes with Imaging-Pathologic correlation. Semin Ultrasound CT MR 2016;37:525-32.

Copyright 2022 BMJ Publishing Group. All rights reserved. For permission to reuse any of this content visit https://www.bmj.com/company/products-services/rights-and-licensing/permissions/

BMJ Case Report Fellows may re-use this article for personal use and teaching without any further permission.

Become a Fellow of BMJ Case Reports today and you can:

- Submit as many cases as you like

- Enjoy fast sympathetic peer review and rapid publication of accepted articles

- Access all the published articles

Re-use any of the published material for personal use and teaching without further permission

Customer Service

If you have any further queries about your subscription, please contact our customer services team on +44 (0) 2071111105 or via email at support@bmj.com.

Visit casereports.bmj.com for more articles like this and to become a Fellow 